\title{
PERBEDAAN PENGARUH PENGGUNAAN METODE PEMBELAJARAN EKSPERIMEN DAN DEMONSTRASI BERBANTUKAN PCB SEDERHANA DITINJAU DARI KREATIVITAS SISWA TERHADAP HASIL BELAJAR SISWA
}

\author{
Andri Desy Astuti ${ }^{1}$, Jeffry Handhika ${ }^{2}$, Sulistyaning Kartikawati ${ }^{3}$ \\ ${ }^{1,3}$ Pendidikan Teknik Elektro, Universitas PGRI Madiun \\ Madiun, 63118, Indonesia \\ ${ }^{2}$ Pendidikan Fisika, FKIP, Universitas PGRI Madiun \\ Madiun, 63118, Indonesia \\ Email: andridesya@gmail.com; jhandhika@unipma.ac.id; sulistyaningk@gmail.com
}

\begin{abstract}
Abstrak. Penelitian ini bertujuan untuk mengetahui: 1) adakah perbedaan pengaruh antara penggunaan metode pembelajaran eksperimen dan demontrasi berbantukan PCB sederhana terhadap hasil belajar siswa; 2) adakah perbedaan pengaruh antara kreativitas kategori tinggi dan rendah terhadap hasil belajar siswa melalui metode pembelajaran eksperimen dan demonstrasi berbantukan PCB sederhana ;3) adakah interaksi antara metode pembelajaran eksperimen, demonstrasi berbantukan PCB sederhana dan kreativitas siswa terhadap hasil belajar siswa.

Penelitian ini berbentuk penelitian kuantitatif. Sampel yang digunakan dua kelas, diambil menggunakan teknik sample random sampling dengan kelas eksperimen pertama diajar dengan metode pembelajaran eksperimen dan kelas eksperimen kedua diajar dengan metode pembelajaran demonstrasi. Teknik pengumpulan data menggunakan metode tes dan metode dokumentasi untuk data kreativitas dan data hasil belajar Dasar dan Pengukuran Listrik siswa. Teknik analisis data menggunakan uji analisis variansi dua jalan sel tak sama dengan matriks $2 \times 2$ dan uji lanjut menggunakan uji Scheffe.

Hasil uji hipotesis dengan taraf signifikansi $(\alpha)=5 \%$ menunjukkan bahwa: 1) $F_{o b s}>$ $\mathrm{F}_{\alpha}(4,004>4,02)$ maka $H_{0 \mathrm{~A}}$ ditolak, sehingga terdapat perbedaan pengaruh antara penggunaan metode pembelajaran eksperimen dan demonstrasi berbantukan PCB Sederhana terhadap hasil belajar siswa; 2) $F_{o b s}>\mathrm{F}_{a}(25,29514>12,0389)$ maka $H_{0 \mathrm{~A}}$ ditolak, sehingga terdapat perbedaan pengaruh antara kreativitas kategori tinggi dan rendah terhadap hasil belajar siswa melalui metode pembelajaran eksperimen dan demonstrasi berbantukan PCB Sederhana; 3) $F_{o b s}>\mathrm{F}_{\alpha}(0,2329>4,02)$ maka $H_{0 \mathrm{~B}}$ diterima, sehingga tidak terdapat interaksi antara metode pembelajaran eksperimen, demonstrasi berbantukan PCB Sederhana dan kreativitas siswa terhadap hasil belajar siswa.
\end{abstract}

Kata Kunci : Eksperimen, Demonstrasi, Kreativitas Berfikir, Hasil Belajar Siswa.

\section{Pendahuluan}

Proses pembelajaran yang baik dimana guru tidak harus berperan sebagai teacher center, justru siswalah yang harus aktif dalam pembelajaran. Siswa harus lebih aktif dalam pembelajaran. Siswa harus terampil menghadapi suatu permasalahan selama proses pembelajaran berlangsung. Serta siswa dapat mengajukan pertanyaan bila ada yang belum dipahami dan mengemukakan pendapatnya sehingga akan lebih aktif dalam proses pembelajaran. Proses pembelajaran adalah suatu kegiatan interaktif yang dilakukan secara sadar antara siswa dan guru dalam suatu lingkungan lembaga pendidikan, dimana guru menyampaikan materi kepada siswa agar siswa dapat terpengaruh memperoleh tujuan dari pendidikan, yaitu mengajarkan siswa menuju perubahan yang lebih baik, baik dalam intelektual, moral serta sosial dalam pencapaian tujuan tersebut perlu adanya interaksi siswa dengan lingkungan belajar yang diatur oleh guru melalui garis proses pembelajaran. 
Sekolah Menengah Kejuruan (SMK) merupakan suatu lembaga pendidikan kejuruan akademis yang berorientasi pada praktik dalam bidang-bidang pertukangan, bisnis, industri, pertanian, transportasi, pelayanan jasa, kesehatan dan lain-lain. Dimana siswanya dipersiapkan untuk dapat langsung bekerja dalam bidang tertentu sesuai dengan keahliannya. Sehingga siswa dibentuk untuk dapat mengembangkan keahlian serta keterampilan yang ada pada tiap siswa, sehingga akan dapat meningkatkan produktifitas, kreativitas, mutu dan efisien kerja. Pada penelitian ini akan diuji cobakan pada mata pelajaran Dasar dan Pengukuran Listrik merupakan mata pelajaran produktif pada jurusan teknik instalasi tenaga listrik yang diajarkan pada kelas X (sepuluh).

Berdasarkan hasil pengamatan yang dilakukan khususnya di kelas X IL SMK Negeri 1 Wonoasri, masih banyak siswa yang mendapatkan nilai mata pelajaran Dasar dan Pengukuran Listrik di bawah KKM/tidak tuntas, dan harus melakukan remidial. Dapat dikatakan siswa belum berhasil dalam proses pembelajaran, sehingga mendapatkan nilai kurang memuaskan. Untuk mencapai nilai KKM/nilai tuntas siswa dalam hasil belajar tidak terlepas pada cara penyajian materi pelajaran dan metode pembelajaran yang digunakan oleh guru. Selama ini di SMK Negeri 1 Wonoasri, sebagian guru menyajikan materi pelajaran Dasar dan Pengukuran Listrik hanya dengan menggunakan metodemetode yang berpusat kepada guru. Dalam hal ini guru bersifat aktif sedangkan siswa bersifat pasif. Sehingga metode pembelajaran ini dinilai kurang efektif digunakan dalam proses pembelajaran.

Salah satu metode pembelajaran yang efektif untuk mata pelajaran Dasar dan Pengukuran Listrik adalah metode pembelajaran eksperimen. Suryani, N. dan Agung, L. (2012: 62) "metode eksperimen (percobaan) adalah cara penyajian pelajaran, di mana siswa melakukan percobaan dengan mengalami dan membuktikan sendiri sesuatu yang dipelajari". Sedangkan menurut Roestiyah (2012: 80) "metode eksperimen adalah salah satu cara mengajar, di mana siswa melakukan suatu percobaan tentang sesuatu hal, mengamati prosesnya serta menuliskan hasil percobaannya, kemudian hasil pengamatan itu disampaikan ke kelas dan dievaluasi oleh guru". Adapun menurut Sartika, S., B. (2012: 191) "metode eksperimen adalah suatu cara penyampaian pengajaran dengan melakukan kegiatan percobaan untuk menemukan sendiri apa yang dipelajari baik secara individu maupun kelompok, sehingga siswa mampu mengecek kebenaran suatu hipotesis atau membuktikan sendiri apa yang dipelajari."

Berdasarkan beberapa pendapat di atas, dapat disimpulkan bahwa metode pembelajaran eksperimen adalah metode pembelajaran eksperimen merupakan kegiatan pembelajaran yang dimana proses pembelajarannya siswa dapat langsung mempraktikkan atau mengaplikasikan materi yang diperoleh dari guru melalui media pembelajaran. Dengan metode pembelajaran eksperimen berbantukan PCB Sederhana siswa dapat mengamati apa yang siswa lihat yang nantinya dapat menimbulkan pertanyaan dari hasil praktik. Sehingga siswa dapat lebih percaya diri dengan hasil praktik yang telah dilaksanakan, yang nantinya dapat meningkatkan hasil belajar siswa.

Selain dengan menggunakan metode pembelajaran eksperimen dapat pula menggunakan metode pembelajaran demonstrasi. Metode pembelajaran demonstrasi. Menurut Suryani, N. dan Agung, L. (2012: 60) "metode demonstrasi adalah cara penyajian bahan pelajaran dengan memperagakan atau mempertunjukkan kepada siswa suatu proses, situasi atau benda tertentu yang sedang dipelajari, baik sebenarnya atau tiruan yang disertai dengan penjelasan". Roestiyah (2012: 83) "demonstrasi adalah cara mengajar dimana seorang instruktur/atau tim guru menunjukkan, memperlihatkan sesuatu proses misalnya merebus air sampai mendidih $100^{\circ} \mathrm{C}$, Sehingga seluruh siswa dalam kelas dapat melihat, mengamati, mendengar mungkin meraba dan merasakan proses yang ditunjukkan oleh guru tersebut". Adapun menurut Sanjaya, W. (2009: 152) "metode demonstrasi adalah metode penyajian pelajaran dengan memperagakan dan mempertunjukkan kepada siswa tentang suatu proses, situasi atau benda tertentu, baik sebenarnya atau hanya sekedar tiruan".

Dari beberapa pendapat di atas, dapat disimpulkan metode pembelajaran demonstrasi adalah suatu kegiatan dimana seorang demonstrator memperagakan atau menunjukkan suatu proses atau tata cara dalam penggunaan suatu media atau objek pembelajaran yang disertai dengan penjelasan. Dengan metode pembelajaran demonstrasi berbantukan PCB Sederhana siswa dapat mengikuti seluruh proses 
dari demonstari mulai dari melihat, mendengarkan serta meraba dari proses yang ditunjukkan oleh demonstrator. Sehingga siswa akan ikut berpartisipasi aktif dalam pembelajaran.

Dengan penggunaan metode pembelajaran eksperimen dan demonstrasi berbantukan PCB Sederhana dapat membantu siswa dalam meningkatkan hasil belajar siswa yang ditinjau dari kreativitas siswa. Menurut Santrok, J., W. (2014: 20) "kreativitas adalah kemampuan untuk berfikir tentang cara baru dan tidak biasa dan datang dengan solusi yang unik". Sedangkan menurut Baihaqi, MIF (2016: 221) "kreativitas (creativity) adalah salah satu kemampuan intelektual manusia yang sangat penting, oleh kebanyakan ahli psikologi kognitif dimasukkan ke dalam kemampuan memecahkan masalah."

Nursisto (2011) (dalam Sumantri, M., S. 2015: 114) mengungkapkan bahwa kemampuan kreatif dapat dibangkitkan melalui masalah yang mengacu pada lima perilaku kreatif, yaitu:

a. Fluency (kelancaran), yaitu kemampuan mengemukakan ide-ide yang serupa untuk memecahkan suatu masalah

b. Flexibility (keluwesan), yaitu kemampuan untuk menghasilkan berbagai macam ide guna memecahkan masalah di luar kategori yang biasa

c. Originality (keaslian), yaitu kemampuan memberikan respon yang unik luar biasa

d. Elaboration (keterampilan), yaitu kemampuan menyatakan pengarahan ide secara terperinci untuk mewujudkan ide menjadi kenyataan

e. Sensitivity (kepekaan), yaitu kepekaan menangkap

Dengan penggunaan metode pembelajaran eksperimen dan demonstrasi berbantukan PCB Sederhana dapat membantu siswa dalam kegiatan praktik mata pelajaran Dasar dan Pengukuran Listrik. Selain dari kegiatan praktik siswa dapat lebih memahami materi yang disampaikan oleh guru, karena siswa dapat mengalami proses disetiap langkah kegitan selama praktik berlangsung. Dimana antara metode eksperimen dan demonstrasi memiliki hubungan yang dapat meningkatkan hasil belajar siswa ditinjau dari kreativitas siswa.

Menurut Purwanto (2014: 45) "hasil belajar merupakan perolehan dari proses belajar siswa sesuai dengan tujuan pengajaran (ends are being attained)". Menurut Suprijono, A. (2013: 7) "hasil belajar adalah perubahan perilaku secara keseluruhan bukan hanya salah satu aspek potensi kemanusiaan saja". Sedangkan menurut Muslich, M. (2011: 38) "hasil belajar merupakan kemampuan-kemampuan yang dimiliki peserta didik setelah ia menerima pengalaman belajar".

Ula, S., S. (2013: 14-17) menyebutkan ciri-ciri perubahan-perubahan yang dihasilkan oleh belajar sebagai berikut:

a. Perubahan terjadi secara sadar

b. Perubahan bersifat positif dan aktif

c. Perubahan bersifat kontinu dan fungsional

d. Perubahan tidak bersifat sementara

e. Perubahan mencakup seluruh aspek tingkah laku

f. Perubahan memiliki tujuan atau terarah

Dari beberapa pendapat di atas, dapat disimpulkan bahwa hasil belajar merupakan sebuah pencapaian siswa dari suatu kegiatan proses pembelajaran untuk hasil yang lebih baik di mana mencakup aspek kognitif, afektif dan psikomotor. Dalam proses pembelajaran yang efektif akan berpengaruh pada hasil belajar yang maksimal. Hasil belajar siswa tidak hanya pada nilai kognitif melainkan juga dari nilai afektif dan nilai psikomotor.

Berdasarkan identifikasi yang telah diuraikan, maka tujuan dari penelitian ini antara lain:

1. Untuk mengetahui adanya perbedaan pengaruh antara penggunaan metode pembelajaran eksperimen dan demontrasi berbantukan PCB Sederhana terhadap hasil belajar siswa.

2. Untuk mengetahui adanya perbedaan pengaruh antara kreativitas kategori tinggi dan rendah terhadap hasil belajar siswa melalui metode pembelajaran eksperimen dan demonstrasi berbantukan PCB Sederhana. 
3. Untuk mengetahui adanya interaksi antara metode pembelajaran eksperimen dan demonstrasi berbantukan PCB Sederhana ditinjau dari kreativitas siswa terhadap hasil belajar siswa.

\section{Metode}

Metode penelitian yang digunakan dalam penelitian ini adalah metode penelitian eksperimen. Metode penelitian eksperimen dilakukan pada siswa kelas X di SMK Negeri 1 Wonoasri yang diambil dua kelas. Metode pembelajaran adalah metode eksperimen berbantukan PCB Sederhana sebagai kelas eksperimen pertama dan model pembelajaran demonstrasi berbantukan PCB Sederhana sebagai kelas eksperimen kedua. Penelitian ini meninjau dari kreativitas siswa

Penelitian disusun sesuai dengan variabel-variabel yang terlibat. Variabel-variabel yang terlibat dalam penelitian ini merupakan cerminan dari data-data yang akan diperoleh setelah perlakuan. Data yang diperoleh kemudian dianalisis menggunakan uji anava dua jalan sel tak sama dengan matriks 2x2. Budiyono (2015: 228) "yang dimaksud dengan sel tak sama ialah bahwa frekuensi masingmasing sel tidak harus sama". Uji hipotesis menggunanak anava dua jalan sel tak sama dengan matriks $2 \times 2$ karena terdapat dua variabel yaitu dua model pembelajaran yang terdiri dari metode pembelajaran eksperimen dan demonstrasi berbantukan PCB Sederhana serta kreativitas siswa yang terdiri dari dua kategori yaitu tinggi dan rendah.

\section{Hasil dan Pembahasan}

Data yang diperoleh dari hasil penelitian yang berupa nilai hasil belajar dan kreativitas siswa dalam mata pelajaran Dasar dan Pengukuran Listrik menggunakan uji anava dua jalan sel tak sama dengan matriks 2x2, dilanjutkan dengan uji Scheffe untuk uji $H_{0 \mathrm{~A}}$ dan $H_{0 \mathrm{~B}}$ yang ditolak. Hasil pengujian hipotesis menggunakan anava dengan taraf signifikan 5\% didapatkan hasil yang terangkum dalam tabel di bawah ini.

Tabel 1. Rangkuman Uji Analisis Variansi (Anava)

\begin{tabular}{lllllll}
\hline Sumber & $J K$ & $D K$ & $R K$ & $F_{\text {obs }}$ & $F_{\alpha}$ & $p$ \\
\hline Baris $(A)$ & 420,978 & 1 & 420,978 & 4,400 & 4,02 & $<0,05$ \\
\hline Kolom $(B)$ & 2485,537 & 1 & 2485,537 & 25,981 & 4,02 & $<0,05$ \\
\hline $\begin{array}{l}\text { Interaksi } \\
(A B)\end{array}$ & 22,285 & 1 & 22,285 & 0,233 & 4,02 & $>0,05$ \\
\hline Galat & 5357,381 & 56 & 95,668 & - & - & - \\
\hline Total & 8286,181 & 59 & - & - & - & - \\
\hline
\end{tabular}

Berdasarkan tabel 1 dapat disimpulkan bahwa:

1) Terdapat perbedaan pengaruh antara metode pembelajaran eksperimen dan metode pebelajaran demonstrasi berbantukan PCB Sederhana terhadap hasil belajar Dasar dan Pengukuran Listrik.

2) Terdapat perbedaan pengaruh kreativitas kategori tinggi dan rendah terhadap hasil belajar siswa melalui metode pembelajaran eksperimen dan demonstrasi berbantukan PCB Sederhana terhadap hasil belajar Dasar dan Pengukuran Listrik.

3) Tidak terdapat interaksi antara metode pembelajaran eksperimen, demonstrasi berbantukan PCB Sederhana dan kreativitas siswa terhadap hasil belajar siswa.

Berdasarkan perhitungan uji analisis variansi (anava) diperoleh keputusan uji $H_{0 \mathrm{~A}}=$ ditolak, $H_{0 \mathrm{~B}}=$ ditolak, $H_{0 \mathrm{AB}}=$ diterima maka langkah selanjutnya adalah uji lanjut pasca anava untuk uji $H_{0 \mathrm{~A}}$ dan $H_{0 \mathrm{~B}}$. Uji lanjut pasca anava yang digunakan pada penelitian ini adalah uji lanjut pasca anava dengan menggunakan metode Scheffe'. Rangkuman hasil analisis data untuk uji lanjut pasca anava dengan taraf signifikansi $\alpha=5 \%$ data hasil belajar Dasar dan Pengukuran Listrik siswa adalah sebagai berikut. 
Tabel 2. Rangkuman Analisis Uji Lanjut Pasca Anava ketika $H_{0 \mathrm{~A}}$ Ditolak

\begin{tabular}{llll}
\hline $\begin{array}{l}\text { Metode } \\
\text { Pembelajaran } \\
(\boldsymbol{A})\end{array}$ & \multicolumn{2}{l}{ Kreativitas $(\boldsymbol{B})$} & Rataan Marginal \\
\cline { 2 - 4 } & Tinggi $\left(B_{1}\right)$ & $\operatorname{Rendah}\left(B_{2}\right)$ & \\
\hline Eksperimen $\left(A_{1}\right)$ & 85,3333 & 73,6667 & 79,5000 \\
\hline Demonstrasi $\left(A_{2}\right)$ & 81,2500 & 67,1429 & 74,6667 \\
\hline Rataan Marginal & 83,2258 & 70,5172 & \\
\hline
\end{tabular}

Berdasarkan tabel 1. dapat disimpulkan bahwa kelas yang menerapkan metode pembelajaran eksperimen berbantukan PCB Sederhana lebih baik hasil belajarnya dibandingkan kelas yang menerapkan metode pembelajaran demonstrasi berbantukan PCB Sederhana.

Tabel 3. Rangkuman Analisis Uji Lanjut Pasca Anava ketika $H_{0 \mathrm{~B}}$ Ditolak

\begin{tabular}{lllcl}
\hline$H_{0}$ & $H_{1}$ & $F_{\text {obs }}$ & $F_{\text {tabel }}$ & Keputusan Uji \\
\hline$\mu_{1}=\mu_{2}$ & $\mu_{1} \neq \mu_{2}$ & 25,29514 & 12,0389 & $H_{0}$ ditolak \\
\hline
\end{tabular}

Berdasarkan tabel 3. dapat disimpulkan bahwa, terdapat perbedaan pengaruh kreativitas kategori tinggi dan rendah terhadap hasil belajar siswa melalui metode pembelajaran eksperimen dan demonstrasi berbantukan PCB Sederhana terhadap hasil belajar Dasar dan Pengukuran Listrik. Dengan perbedaan rataan yang signifikan antara hasil belajar Dasar dan Pengukuran Listrik pada kelompok siswa dengan kreativitas kategori tinggi dan hasil belajar Dasar dan Pengukuran Listrik pada kelompok siswa dengan kreativitas kategori rendah.

Berdasarkan penjelasan tentang hasil pengujian hipotesis di atas, maka pembahasan masingmasing hipotesis adalah sebagai berikut:

1. Pembahasan Hipotesis Pertama

Berdasarkan hasil analisis uji hipotesis menunjukkan bahwa $F_{o b s}=4,004$ sedangkan $\mathrm{F}_{\alpha}=4,02$. Diketahui bahwa $F_{o b s}>\mathrm{F}_{\alpha}(4,004<4,02)$, maka $H_{0 \text { A }}$ ditolak. Hal ini menunjukkan terdapat perbedaan pengaruh antara penerapan metode pembelajaran eksperimen berbantukan PCB Sederhana dan metode pembelajaran demonstrasi berbantukan PCB Sederhana terhadap hasil belajar Dasar dan Pengukuran Listrik siswa.

Berdasarkan uji hipotesis dengan metode Scheffe' didapat bahwa hasil dari rerata marginal dari metode pembelajaran eksperimen berbantukan PCB Sederhana adalah 79,5000 sedangkan metode pembelajaran demonstrasi berbantukan PCB Sederhana adalah 74,6667, sehingga didapat bahwa metode pembelajaran eksperimen berbantukan PCB Sederhana lebih baik dibandingkan dengan metode pembelajaran demonstrasi berbantukan PCB Sederhana.

Dengan demikian metode pembelajaran eksperimen berbantukan PCB Sederhana dapat memberikan pengaruh lebih terhadap hasil belajar siswa dibandingkan menggunakan metode pembelajaran demonstrasi berbantukan PCB Sederhana. Hal ini dapat dibuktikan dengan rata-rata nilai hasil belajar siswa sebelum perlakuan lebih kecil dari nilai rata-rata hasil belajar siswa setelah perlakuan. Dengan metode pembelajaran eksperimen berbantukan PCB Sederhana lebih dapat menggerakkan ide dan melibatkan siswa pada keseluruhan aktivitas belajar. Serta dengan metode pembelajaran eksperimen berbantukan PCB Sederhana menutut kejelian dan ketepatan siswa dalam melakukan pengamatan serta pengambilan data pada saat percobaan sehingga siswa lebih memahami materi serta pembelajaran akan semakin bermakna bagi siswa. Dibandingkan dengan metode pembelajaran demonstrasi berbantukan PCB Sederhana dimana siswa hanya dapat 
melihat dan merekam data yang telah diperagakan oleh guru sehingga siswa hanya terfokus pada teori-teori saja. Siswa juga akan kurang mampu menganalisis dalam menyelesaikan permasalahan yang diberikan oleh guru.

Hal ini sesuai dengan penelitian yang dilakukan oleh Handika, J. (2010) yang terpublikasi dalam jurnal JP2F dengan judul "Pembelajaran Fisika Melalui Inkuiri Terbimbing dengan Metode Eksperimen dan Demonstrasi Ditinjau dari Aktivitas dan Perhatian Mahasiswa". Penelitian ini yang dilakukan Handika, J. (2010: 15) menghasilkan pembelajaran Fisika dengan menggunakan metode eksperimen lebih baik daripada pembelajaran Fisika dengan menggunakan metode demonstrasi, hal ini dikarenakan metode eksperimen mempunyai keunggulan dibanding dengan metode demonstrasi.

2. Pembahasan Hipotesis Kedua

Dari hasil pengujian hipotesis diperoleh data hasil uji hipotesis menunjukkan bahwa bahwa $F_{o b s}=$ 25,9810 sedangkan $\mathrm{F}_{\alpha}=4,02$. Diketahui bahwa $F_{o b s}>\mathrm{F}_{\alpha}(25,9810<4,02)$, maka $H_{0 \mathrm{~A}}$ ditolak. Sehingga menunjukkan bahwa adanya perbedaan pengaruh kreativitas tinggi dan rendah terhadap hasil belajar Dasar dan Pengukuran Listrik siswa.

Berdasarkan uji analisis variansi dengan metode Scheffe', menunjukkan hasil yang didapat $F_{l-2}=25,29514$ sedangkan $\mathrm{F}_{\text {tabel }}=12,0389$. Diketahui bahwa $F_{o b s}>\mathrm{F}_{\alpha}(25,29514>12,0389)$, sehingga berdasarkan uji hipotesis tersebut diperoleh adanya perbedaan pengaruh antara hasil belajar Dasar dan Pengukuran Listrik pada kelompok siswa dengan kreativitas kategori tinggi dan hasil belajar Dasar dan Pengukuran Listrik pada kelompok siswa dengan kreativitas kategori rendah. Dari hasil rataan marginal pada kelompok siswa dengan kreativitas kategori tinggi lebih besar dari kelompok siswa kreativitas kategori rendah, yaitu 83,2258 > 70,5172. Sehingga hasil belajar Dasar dan Pengukuran Listrik pada kelompok siswa dengan krativitas kategori tinggi lebih baik daripada hasil belajar Dasar dan Pengukuran Listrik pada kelompok siswa dengan kreativitas kategori rendah.

Meningkatnya nilai hasil belajar Dasar dan Pengukuran Listrik siswa dipengaruhi oleh tinggi rendahnya kreativitas siswa. Siswa yang mempunyai kreativitas kategori tinggi cenderung mempunyai rasa yakin terhadap dirinya sendiri, tidak bergantung kepada orang lain dan bertanggung jawab dalam memecahkan permasalahan yang diberikan. Sedangkan, siswa yang mempunyai kreativitas kategori rendah cenderung kurang mempunyai rasa yakin terhadap dirinya sendiri, bergantung kepada orang lain dan kurang bertanggung jawab dalam memecahkan permasalahan yang diberikan.

Hal ini sesuai dengan penelitian yang dilakukan oleh Parmono (2013) yang terpublikasi dalam jurnal inquiri dengan judul "Pembelajaran Fisika dengan Pendekatan CTL Melalui Metode Eksperimen dan Demonstrasi Ditinjau dari Kreativitas dan Gaya Belajar Siswa". Penelitian ini yang dilakukan Parmono (2013: 41) menghasilkan siswa dengan kategori kreativitas tinggi memperoleh prestasi belajar rata-rata kognitif, afektif dan keterampilan proses lebih tinggi dari pada kreativitas rendah.

3. Pembahasan Hipotesis Ketiga

Berdasarkan hasil analisis uji hipotesis menunjukkan bahwa $F_{o b s}=0,2329$ sedangkan $F_{\alpha}=4,02$. Diketahui bahwa $F_{o b s}>\mathrm{F}_{\alpha}(0,2329>4,02)$, maka $H_{0 \mathrm{~B}}$ diterima. Dari hasil pengujian hipotesis tersebut diperoleh kesimpulan bahwa tidak terdapat interaksi antara metode pembelajaran eksperimen, demonstrasi berbantukan PCB Sederhana dan kreativitas siswa terhadap hasil belajar siswa. Pada kelas X IL 3 dengan metode pembelajaran eksperimen berbantukan PCB Sederhana menunjukan bahwa siswa yang memiliki kreativitas kategori tinggi memperoleh hasil belajar yang lebih baik daripada siswa yang memiliki kreativitas kategori rendah. Pada kelas X IL 1 dengan metode pembelajaran demonstrasi berbantukan PCB Sederhana menunjukan bahwa siswa yang memiliki kreativitas kategori tinggi juga memperoleh hasil belajar yang lebih baik daripada siswa yang memiliki kreativitas kategori rendah. 


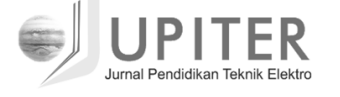

jupiterfptk@ikippgrimadiun.ac.id

Hasil belajar pada pembelajaran baik menggunakan metode pembelajaran eksperimen berbantukan PCB Sederhana maupun metode pembelajaran demonstrasi berbantukan PCB Sederhana pada siswa yang memiliki kreativitas kategori tinggi lebih baik daripada siswa yang memiliki kreativitas kategori rendah. Ini berarti tidak ada perbedaan antara metode pembelajaran yang digunakan yaitu metode pembelajaran eksperimen, metode pembelajaran demonstrasi dengan kreativitas siswa terhadap hasil belajar siswa. Pada siswa yang memiliki kreativitas kategori tinggi akan lebih aktif dalam proses pembelajaran dan dapat menerima materi pelajaran yang disampaikan oleh guru dengan cepat. Sedangkan pada siswa yang memiliki kreativitas kategori rendah cenderung kurang aktif dalam proses pembelajaran, karena siswa kurang percaya diri dalam menyampaikan pendapat atau ide yang dimilikinya serta kurang cepat dalam menerima materi yang disampaikan oleh guru. Meskipun tidak ada interaksi yang signifikan antar varibelvariabelnya, di mana metode pembelajaran eksperimen berbantukan PCB Sederhana yang awalnya secara teori diharapkan lebih baik, namun dalam penerapannya memberikan hasil yang kurang efektif yang sama halnya dengan metode pembelajaran demonstrasi berbantukan PCB Sederhana. Sedangkan ketika dilihat dari rata-rata nilai yang diperoleh siswa menunjukan bahwa variabel-variabel tersebut memiliki dampak yang baik terhadap hasil belajar siswa karena secara garis besar siswa mampu mendapatkan nilai di atas KKM yang telah ditentukan.

Hal ini sesuai dengan penelitian yang dilakukan oleh Handika, J. (2010) yang terpublikasi dalam jurnal JP2F dengan judul "Pembelajaran Fisika Melalui Inkuiri Terbimbing dengan Metode Eksperimen dan Demonstrasi Ditinjau dari Aktivitas dan Perhatian Mahasiswa". Penelitian ini yang dilakukan Handika, J. (2010: 18) menghasilkan bahwa tidak terjadi interaksi metode pembelajaran dengan aktivitas, karena dengan metode eksperimen maupun demonstrasi, semakin tinggi tingkat aktivitas, akan semakin tinggi pula penguasaan konsep.

\section{Simpulan}

Berdasarkan hasil analisis dan pembahasan yang telah dipaparkan, maka diperoleh kesimpulan sebagai berikut:

1. Berdasarkan hasil analisis uji hipotesis dengan metode Scheffe', menunjukkan hasil yang didapat $F_{o b s}=4,004$ sedangkan $\mathrm{F}_{\alpha}=4,02$ dan taraf signifikan 5\%. Diketahui bahwa $F_{o b s}>\mathrm{F}_{\alpha}(4,004>$ 4,02) maka $H_{0 \mathrm{~A}}$ ditolak. Sehingga dapat disimpulkan bahwa terdapat perbedaan pengaruh antara penggunaan metode pembelajaran eksperimen dan demonstrasi berbantukan PCB Sederhana terhadap hasil belajar siswa. Karena metode pembelajaran eksperimen berbantukan PCB Sederhana membuat siswa lebih aktif dan dapat membuktikan sendiri kebenaran dari suatu teori. Sedangkan dengan metode pembelajaran demonstrasi berbantukan PCB Sederhana siswa kurang aktif dalam pembelajaran, dimana siswa hanya mendapat hasil dari demonstrasi yang telah guru lakukan.

2. Berdasarkan hasil analisi uji hipotesis dengan metode Scheffe', menunjukkan hasil yang didapat $F_{1-2}=25,29514$ sedangkan $\mathrm{F}_{\text {tabel }}=12,0389$ dan taraf signifikan 5\%. Diketahui bahwa $F_{o b s}>\mathrm{F}_{\alpha}$ $(25,29514>12,0389)$ maka $H_{0 A}$ ditolak. Sehingga dapat disimpulkan bahwa terdapat perbedaan pengaruh antara kreativitas kategori tinggi dan rendah terhadap hasil belajar siswa melalui metode pembelajaran eksperimen dan demonstrasi berbantukan PCB Sederhana. Karena siswa dengan kreativitas kategori tinggi dapat memahani dengan cepat apa yang telah disampaikan guru, sedangkan siswa dengan kreativitas kategori rendah akan sedikit sulit untuk memahami materi yang telah disampaikan oleh guru.

3. Berdasarkan hasil analisis uji hipotesis menunjukkan hasil yang didapat $F_{o b s}=0,2329$ sedangkan $\mathrm{F}_{\alpha}=4,02$ dan taraf signifikan 5\%. Diketahui bahwa $F_{o b s}>\mathrm{F}_{\alpha}(0,2329>4,02)$ maka $H_{0 \mathrm{~B}}$ diterima. Sehingga dapat disimpulkan bahwa tidak terdapat interaksi antara metode pembelajaran eksperimen, demonstrasi berbantukan PCB Sederhana dan kreativitas siswa terhadap hasil belajar siswa. Karena siswa mempunyai kemampuan dan cara mengembangkan kemampuan yang dimilikinya berbeda-beda. Sehingga dengan metode pembelajaran eksperimen maupun 
demonstrasi berbantukan PCB Sederhana terhadap hasil belajar Dasar dan Pengukuran Listrik yang ditinjau dari kreativitas siswa memberikan pengaruh yang sama.

\section{Daftar Pustaka}

[1] Budiyono. (2015). Statistika untuk Penelitian. Surakarta: UNS Press.

[2] Baihaqi, MIF. (2016). Pengantar Psikologi Kognitif. Bandung: PT. Refika Aditama.

[3] Handika, J. (2010). Pembelajaran Fisika Melalui Inkuiri Terbimbing dengan Metode Eksperimen dan Demonstrasi Ditinjau dari Aktivitas dan Perhatian Mahasiswa. JP2F. (https://scholar.google.co.id, diunduh pada 02 Mei 2017)

[4] Muslich, M. (2011). Penilaian Berbasis Kelas dan Kompetensi. Bandung: PT Refika Aditama

[5] Parmono, Sunarno, W., dan Suparmi. (2013). Pembelajaran Fisika dengan Pendekatan CTL melalui Metode Eksperimen dan Demonstrasi ditinjau dari Kreativitas dan Gaya Belajar Siswa. Jurnal Inkuiri, 2 (1), 33-42. (https://jurnal.fkip.uns.ac.id/index.php/sains, diunduh pada 02 Mei 2017)

[6] Purwanto. (2014). Evaluasi Hasil Belajar. Yogyakarta: Pustaka Pelajar.

[7] Sartika, S. B. (2012). Pengaruh Penerapan Metode Eksperimen Sebagai Implementasi Kurikulum Tingkat Satuan Pendidikan(KTSP) Terhadap Prestasi Belajar Siswa. Pedagogia, 1 (2), 189-211. (https://ojs.umsida.ac.id, 20 Maret 2017)

[8] Roestiyah. (2012). Strategi Belajar Mengajar. Jakarta: PT Rineka Cipta.

[9] Sanjaya, W. (2009). Strategi Pembelajaran Berorientasi Standar Proses Pendidikan. Jakarta: Prenada Media Group.

[10] Suryani, N., dan Agung, L. (2012). Strategi Belajar Mengajar. Yogyakarta: Penerbit Ombak.

[11] Suprijono, A. (2013). Cooperative Learning Teori dan Aplikasi PAIKEM. Yogyakarta: Pustaka Pelajar.

[12] Santrok, J. W. (2014). Psikilogi Pendidikan. Jakarta: Salemba Humanika.

[13] Sumantri, M. S. (2015). Strategi Pembelajaran: Teori dan Praktik di Tingkat Pendidikan Dasar. Jakarta: Raja Grafindo Persada.

[14] Ula, S. (2013). Revolusi Belajar: Optimalisasi Kecerdasan melalui Pembelajaran Berbasis Kecerdasan Majemuk. Maguwoharjo: Ar-Ruzz MediaDaftar Pustaka 